\title{
RETENSI FORTIFIKAN VITAMIN A DAN $\beta$-KAROTEN DALAM MINYAK GORENG SAWIT SELAMA PEMASAKAN
}

\section{[Vitamin A and $\beta$-Carotene Retention as Fortificant in Palm Oil During Cooking]}

\author{
Drajat Martianto ${ }^{1,3)}$, Nuri Andarwulan ${ }^{2,3) \star}$, dan Yoga Putranda ${ }^{2)}$ \\ 1) Departemen IImu Gizi, Fakultas Ekologi Manusia, Institut Pertanian Bogor, Bogor \\ 2) Departemen Ilmu dan Teknologi Pangan, Fakultas Teknologi Pertanian, Institut Pertanian Bogor, Bogor \\ ${ }^{3)}$ Southeast Asian Food and Agricultural Science and Technology (SEAFAST) Center, Institut Pertanian Bogor, Bogor
}

Diterima 26 Februari 2018 / Disetujui 15 Agustus 2018

\begin{abstract}
This study was carried out to obtain information on fortificants (vitamin A and $\beta$-carotene) stability in fortified palm oil. Four types of fortified palm oils were used in this research: palm oil fortified with red palm oil or RPO (containing $\beta$-carotene) $47.08 \mathrm{IU} / \mathrm{g}$, vitamin A (Retinyl palmitate) $56.59 \mathrm{IU} / \mathrm{g}$, combination A (targeted concentration of $30 \mathrm{IU} \beta$-carotene RPO and $15 \mathrm{IU}$ vitamin A) $45.65 \mathrm{IU} / \mathrm{g}$ and combination $B$ (targeted concentration of $15 \mathrm{IU} \beta$-carotene RPO and $30 \mathrm{IU}$ vitamin A) $45.95 \mathrm{IU} / \mathrm{g}$. These fortified oils were then used for shallow frying and sautéing (stir frying). Tofu was used in shallow frying and the oil was reused three times each day for several days. Meanwhile, bean sprout was used for sautéing. The used oils after shallow frying was then analyzed for vitamin $A$ and $\beta$-carotene retention, as well as its other characteristics such as peroxide value and free fatty acid (FFA) content. The sauted sprouts was also analyzed for its fortificants retention. The capacity of oil to retain vitamin $A$ and $\beta$-carotene decreased over the repeated use in frying. During the first frying, the retention of fortificants was not significanly differrent $(P=0.05)$. In the second and third frying, $\beta$-carotene was less retained than the vitamin $A$. Fortificant combination $A$ and $B$ had similar stability. The peroxide value of the oils increased until the second frying, then decreased. Starting the fourth use, the FFA percentage has not increased much hardly increased. The highest yield of fortificant in sautéed sprouts was vitamin $A$ (63.37\%), followed by combination $B(53.42 \%)$, combination A (50.60\%), and RPO (34.86\%). Sautéed sprout (150 g) contained fortificant contributing to the fulfillment of vitamin $A$ adequacy of $32.71-92.93 \%$.
\end{abstract}

Keywords: $\beta$-carotene, fortified palm oil, sautéing, shallowfrying, vitamin $A$

\begin{abstract}
ABSTRAK
Penelitian ini didesain untuk memperoleh informasi mengenai stabilitas fortifikan (vitamin $A$ dan $\beta$ karoten) dalam minyak sawit. Terdapat empat jenis minyak terfortifikasi yang digunakan dalam penelitian ini, yaitu minyak sawit yang difortifikasi dengan minyak sawit merah (MSM) yang mengandung $\beta$-karoten $(47,08 \mathrm{lU} / \mathrm{g})$, vitamin $\mathrm{A}(56,59 \mathrm{IU} / \mathrm{g})$, kombinasi $\mathrm{A}$ (campuran dengan target $30 \mathrm{IU} \beta$-karoten MSM, $15 \mathrm{IU}$ vitamin A) 45,65 IU/g dan kombinasi B (campuran dengan target $15 \mathrm{IU} \beta$-karoten MSM, 30 IU vitamin A) $45,95 \mathrm{lU} / \mathrm{g}$ ). Minyak terfortifikasi ini kemudian digunakan dalam proses pemasakan yang berbeda, dalam proses shallow frying atau menumis yang diulang sebanyak tiga kali dalam satu hari dan dalam beberapa hari, serta dalam proses penumisan. Tahu digunakan dalam proses shallow frying sementara tauge digunakan dalam penumisan. Minyak yang telah digunakan dalam metode shallow frying kemudian dianalisis untuk menentukan retensi vitam in A dan $\beta$-karotennya, serta karakteristik lainnya seperti bilangan peroksida dan asam lemak bebas. Sementara itu tauge yang telah ditum is juga kemudian dianalisis untuk menentukan retensi fortifikannya. Kemampuan minyak dalam mempertahankan kandungan vitamin A dan $\beta$-karotennya menurun seiring dengan jumlah penggorengan yang dilakukan. Dalam proses penggorengan pertama, retensi fortifikan antara beberapa jenis minyak tidak berbeda signifikan $(P=0,05)$. Pada proses penggorengan kedua dan ketiga, $\beta$-karoten dipertahankan dalam jumlah lebih sedikit dibandingkan vitam in A. Fortifikan kombinasi A dan B mempunyai stabilitas yang serupa. Bilangan peroksida minyak juga mengalami peningkatan hingga penggorengan kedua, namun selanjutnya mengalami penurunan. Kandungan asam lemak bebas dari minyak tidak banyak meningkat. Fortifikan terbanyak yang terdapat pada tauge tumis merupakan vitamin A $(63,37 \%)$, disusul oleh kombinasi B $(53,42 \%)$, kombinasi A $(50,60 \%)$, dan $\operatorname{MSM}(34,86 \%)$. Hasil tumisan $(150 \mathrm{~g})$ yang mengandung fortifikan menyumbang pemenuhan kecukupan vitamin A sebesar 32.71-92.93\%.
\end{abstract}

Kata kunci: $\beta$-karoten, fortifikasi minyak goreng sawit, penumisan, shallow frying, vitamin A

*Penulis Korespondensi:

E-mail: andarw ulan@apps.ipb.ac.id 


\section{PENDAHULUAN}

Kekurangan vitamin A merupakan salah satu masalah kesehatan di negara berkembang. Salah satu strategi untuk mengatasi fenomena ini adalah dengan fortifikasi vitamin A ke dalam bahan pangan. Fortifikasi minyak dengan vitamin A telah dicanangkan dan dilakukan di berbagai negara seperti Thailand (Puysuwan et al., 2007), Nigeria (Oni, 2012), Pakistan (Akhtar et al., 2012), Uganda (Fiedler dan Afidra, 2010), dan Indonesia (Andarwulan et al., 2014).

Program fortifikasi vitamin A melalui minyak goreng kelapa sawit di Indonesia dilakukan dengan beberapa pertimbangan. Alasan pertama adalah karena kompatibilitas minyak dengan vitamin $A$. Vitamin A bersifat larut dalam lemak sehingga mudah untuk diinkorporasikan dalam minyak. Minyak juga menstabilkan retinol dan menunda oksidasi dari vitamin. Dalam jumlah cukup minyak juga dapat memengaruhi keberhasilan penyerapan vitamin $A$ (Nadimin dan Tamrin, 2013). Kedua, produksi minyak goreng di Indonesia kebanyakan tersentralisasi. Alasan ketiga adalah karena sebagian besar masakan Indonesia dibuat menggunakan minyak goreng, termasuk jenis masakan yang paling digemari di Indonesia (Achadi et al., 2010).

Fortifikasi vitamin A di Indonesia pada umum nya dilakukan dengan fortifikan sintetik seperti retinil palmitat (Andarwulan et al., 2014). Sayangnya fortifikan sintetik ini masih terbilang mahal karena harus diimpor dari luar negeri. Salah satu alternatif untuk mengatasi masalah tersebut adalah dengan menggunakan sumber vitamin A alami sebagai fortifikan. Marliyati et al. (2010) mencantumkan bahwa minyak sawit merah (MSM) dapat digunakan untuk memenuhi kebutuhan vitamin A sebagai fortifikan alami. Van Rooyen et al. (2008) menyebutkan bahwa minyak sawit merah mengandung sebesar 500 ppm karotenoid yang terdiri atas atas $37 \%$-karoten, $47 \% \beta$-karoten, $1,5 \%$ likopen, serta $6,9 \%$ cis $\alpha-k a-$ roten. Karotenoid berupa $\alpha$-karoten, $\beta$-karoten, $\gamma$ karoten, dan $\beta$-kriptoxanthin ini diketahui memiliki aktivitas provitamin A (Bohn, 2008).

Sayangnya Akhtar et al. (2012) menemukan bahwa proses pemasakan dapat berakibat pada hilangnya kandungan vitamin $A$ dalam minyak terfortifikasi. Jumlah vitamin A yang hilang terkait dengan makin tingginya suhu yang digunakan dan lamanya proses pemasakan. Semakin lama proses pemasakan dan semakin tingginya suhu yang digunakan akan berakibat pada retensi vitamin A yang lebih rendah. Mengingat potensi minyak sawit merah sebagai fortifikan alami, diperlukan penelitian untuk mengetahui retensi vitamin A dan pro-vitamin A pada minyak goreng yang difortifikasi dengan vitamin A sintetik dan minyak sawit merah selama proses pemasakan. Penelitian ini dilakukan untuk menda- patkan informasi pengaruh jenis fortifikan terhadap retensi vitamin $A$ dan $\beta$-karoten pada minyak goreng fortifikasi yang digunakan untuk menggoreng dan menumis. Informasi perubahan mutu minyak selama penggorengan juga diamati. Atribut mutu minyak yang diamati meliputi bilangan peroksida dan asam lemak bebas.

\section{BAHAN DAN METODE}

\section{Bahan}

Bahan yang digunakan dalam penelitian ini adalah minyak sawit curah (PT. Multimas Nabati Asahan, Indonesia), minyak sawit merah (SEAFAST IPB, Indonesia) vitamin A palmitat (the Global Alliance for Improved Nutrition premix facility, Switzerland), serta bahan-bahan yang akan digunakan dalam proses penggorengan dan pemasakan seperti tauge, tahu putih, bawang merah, bawang putih, cabai merah, cabai rawit, dan garam (pasar Cibeureum Bogor, Indonesia).

\section{Pencampuran minyak dengan fortifikan (Vitamin A/Retinil palmitat, MSM yang mengandung $\beta$ - karoten)}

Fortifikan ditambahkan untuk mendapatkan target fortifikasi $45 \mathrm{lU} / \mathrm{g}$ vitamin $\mathrm{A}$. Terdapat 4 jenis fortifikan yang digunakan, yaitu fortifikan vitamin $A$, fortifikan MSM, fortifikan A (terdiri atas $30 \mathrm{lU} / \mathrm{g}$ vitamin $A$ dan $15 \mathrm{lU} / \mathrm{g} \mathrm{MSM})$, dan fortifikan B (15 $\mathrm{IU} / \mathrm{g}$ vitamin A dan $30 \mathrm{lU} / \mathrm{g}$ MSM). Fortifikan ditambahkan sedikit demi sedikit ke dalam minyak dengan disertai pengadukan. Pengadukan dilakukan dengan stirrer berkecepatan 180-200 rpm dalam wadah tertutup yang terlindung dari cahaya. Waktu pengadukan campuran minyak dan MSM adalah selama 45 menit. Campuran minyak dan vitamin A diaduk selama 90 menit, sementara pengadukan campuran minyak dengan fortifikan A dan B dilakukan selama 60 menit. Khusus dalam proses pencampuran fortifikan A dilakukan pre-mixing terlebih dahulu. Pre-mixing dilakukan dengan mencampur vitamin A dengan 50 $\mathrm{g}$ minyak goreng curah di dalam gelas piala selama 15 menit dengan stirrer (IKA RW 20 Digital, China).

Minyak yang telah diberi fortifikan kemudian diuji homogenitasnya. Uji homogenitas dilakukan dengan mengambil sampel minyak dari 4-5 titik pada tempat pencampuran minyak. Titik-titik sampling tersebut ditetapkan pada tempat dan ketinggian yang berbeda (Gambar 1).

\section{Tahapan penggorengan berulang pada hari yang berbeda}

Tahu $\left(5 \times 4 \times 1,5 \mathrm{~cm}^{3}\right)$ dengan bobot $35 \pm 4 \mathrm{~g}$ direndam dalam air garam (10 g garam dalam $300 \mathrm{~mL}$ air) selama 5 menit. Tahu kemudian ditiriskan selama 5 menit sebelum digoreng dengan $400 \mathrm{~g}$ minyak 
fortifikasi yang telah dipanaskan hingga mencapai $170^{\circ} \mathrm{C}$. Tahu digoreng selama 1,5 menit pada satu sisi dan 1 menit pada sisi lainnya. Sebanyak $120 \mathrm{~g}$ minyak diambil sebagai sampel setelah dilakukan penggorengan selama 15 menit. Sampel minyak disimpan dalam botol tertutup dan dilapisi alumunium foil setelah 45 menit. Sisa minyak kemudian disimpan pada wadah yang transparan, ditutup, dan disimpan dalam tempat gelap. Siklus penggorengan selanjutnya dilakukan pada jam yang sama pada hari berikutnya. Penggorengan dilakukan dengan perbandingan minyak dan tahu 4:1 (v:b) (shallow frying) sebanyak satu siklus penggorengan dengan dua ulangan per hari selama tiga hari berturut-turut. Selama penggorengan tidak dilakukan penambahan minyak.

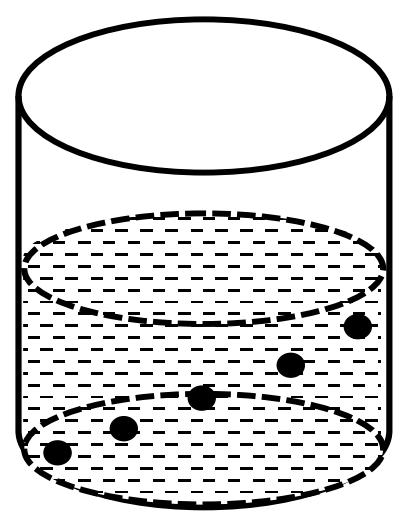

Gambar 1. Titik sampling uji homogenitas

\section{Tahapan penggorengan berulang pada hari yang sama}

Tahap penelitian ini merupakan tahap yang sama dengan tahapan penggorengan berulang pada hari yang berbeda, namun tahapan penggorengannya dilakukan pada hari yang sama sebanyak tiga siklus penggorengan dengan dua ulangan.

\section{Tahapan menumis tauge}

Bahan-bahan yang akan ditumis adalah tauge $(500 \mathrm{~g})$, tahu $2 \times 2 \times 1 \mathrm{~cm}^{3}(100 \mathrm{~g})$, bawang merah (25 $\mathrm{g}$ ), bawang putih ( $8 \mathrm{~g}$ ), cabai rawit hijau (15 g), cabai merah (15 g), garam (8 g) dan air (12 g). Minyak sebanyak $60 \mathrm{~g}$ dipanaskan dalam wajan hinga mencapai $160^{\circ} \mathrm{C}$, kemudian dengan segera dimasukkan bawang putih (ditumis 10 detik), bawang merah (ditumis 10 detik), cabai rawit hijau dan cabai merah (ditumis 1 menit), tahu (ditumis 2 menit), tauge, garam dan air. Setelah semua bahan dimasukkan, penumisan dilanjutkan hingga waktu total penumisan mencapai 9 menit. Tumis tauge segera diangkat dari wajan setelah penumisan selesai. Begitu waktu 45 menit telah berlalu sejak dimulainya penumisan, sampel dimasukkan ke dalam plastik dan disimpan dalam freezer.

\section{Ekstraksi minyak dari bahan yang ditumis (Folch et al., 1957)}

Tumis tauge dibekukan semalaman dan dikeringkan dengan freeze drier (Labconco, USA) selama 3 hari. Sampel yang telah kering kemudian dihaluskan dengan blender dan diekstrak minyaknya. Ekstraksi dilakukan dengan menambahkan $3 \mathrm{~g}$ sampel ke $20 \mathrm{~mL} \mathrm{CHCl}$-MeOH (2:1) (Merck, Germany) dalam labu erlenmeyer. Campuran diaduk selama 1 jam dan disaring, Hasil saringan ditambahkan dengan $4 \mathrm{~mL} \mathrm{NaCl}$ (Merck, Germany) 0,88\% dan dicampur. Lapisan bawah yang terpisah diambil, kemudian diuapkan pelarutnya dengan menggunakan rotavapor vakum (Rotavapor-210 Buchi, Switzerland) suhu $40-50^{\circ} \mathrm{C}$. Minyak yang diperoleh kemudian dihembus dengan gas $\mathrm{N}_{2}$ (CV. Krakatau Raya, Indonesia) hingga tercapai berat konstan. Minyak disimpan dalam botol gelap dalam freezer untuk kemudian dianalisis vitamin $A$ dan $\beta$-karotennya.

\section{Analisis vitamin A (Dever et al. 2011)}

Metode analisis vitamin A dilakukan dalam tiga tahap, yaitu tahap pembuatan kurva standar, tahap persiapan sampel, dan perhitungan kadar vitamin A. Tahap pembuatan kurva standar dilakukan dengan membuat 7 seri konsentrasi retinil asetat (Sigma Aldrich Corporation, Singapore) $(0.5 ; 1 ; 1.5 ; 2 ; 2.5$; 5; 10; 20; 30; 40; 50 ppm), kemudian $750 \mu \mathrm{L}$ etanol (Merck, Germany) dan $400 \mu \mathrm{L}$ larutan KOH (J.T. Baker, USA) dengan $\mathrm{H}_{2} \mathrm{O}$ (50:50) ditambahkan kedalamnya. Campuran dipanaskan pada waterbath $45^{\circ} \mathrm{C}$ selama 1 jam. Sampel diekstrak dengan heksan (Merck, Germany) 0,5 mL 3 kali. Kemudian hasil ekstraksi sampel dievaporasi dengan $\mathrm{N}_{2}$ sampai kering. Sampel dilarutkan dalam $100 \mu \mathrm{L}$ campuran MeOH (Merck, Germany) dan DCM (J.T. Baker, USA) dengan perbandingan 75:25. Larutan diinjeksikan dalam HPLC (Shimadzu Coorporation, Japan) dengan kolom Eclipse XDB-C18 diameter $5 \mu \mathrm{m}$; fase gerak metanol:air (89:11); laju alir $1 \mathrm{~mL} / \mathrm{menit}$; sistem isokratik; panjang gelombang $335 \mathrm{~nm}$; waktu running 12 menit.

Tahap persiapan sampel dilakukan dengan mengambil $25 \mu \mathrm{L}$ minyak sampel, kemudian ditambahkan $750 \mu \mathrm{L}$ etanol dan $400 \mu \mathrm{L} \mathrm{KOH}: \mathrm{H}_{2} \mathrm{O}$ 50:50. Campuran dipanaskan pada waterbath suhu $45^{\circ} \mathrm{C}$ selama 1 jam. Sampel diekstrak dengan heksan 0,5 $\mathrm{mL} 3$ kali. Kemudian hasil ekstraksi sampel dievaporasi dengan $\mathrm{N}_{2}$ sampai kering. Sampel dilarutkan dalam $100 \mu \mathrm{L}$ MeOH:DCM 75:25 dan diinjeksikan dalam HPLC (kolom Eclipse XDB-C18 diameter 5 $\mu \mathrm{m}$; fase gerak metanol:air (89:11); laju alir $1 \mathrm{~mL} /$ menit; sistem isokratik; panjang gelombang $335 \mathrm{~nm}$; waktu running 12 menit).

Kadar vitamin A dihitung dengan menggunakan persamaan regresi linear kurva standard $Y=a+b X$, dengan $Y$ merupakan luas area dan $X$ merupakan konsentrasi vitamin A (dalam $\mu \mathrm{g} / \mathrm{mL}$ retinol). Kadar 
vitamin A yang diperoleh dalam satuan $\mu \mathrm{g} / \mathrm{mL}$ retinol dikonversi ke dalam IU/g.

\section{Analisis $\beta$-karoten (Chiu et al., 2009 termodifi- kasi)}

Sebanyak $5 \mathrm{~g}$ sampel minyak dilarutkan dalam $25 \mathrm{~mL}$ heksana (pro-analysis). Larutan dikocok hingga homogen. Larutan kemudian dianalisis dengan spektofotometer (Shimadzu Coorporation, Japan) pada panjang gelombang $446 \mathrm{~nm}$. Modifikasi metode Chiu et al. (2009) yang dilakukan adalah jumlah sampel yang dilarutkan $(0,1 \mathrm{~g})$ dan penggunaan pelarut heksana (spectroscopic grade).

\section{Analisis kadar air (AOAC, 1984)}

Kadar air produk yang ditumis diukur menggunakan metode oven. Sebanyak $5 \mathrm{~g}$ produk ditimbang ke dalam cawan aluminium yang sebelumnya telah dikeringkan pada suhu $105^{\circ} \mathrm{C}$ selama 2 jam dan diketahui beratnya. Pengeringan dalam oven dilakukan pada suhu $100-102^{\circ} \mathrm{C}$ hing ga diperoleh berat yang tetap.

\section{Analisis kadar asam lemak bebas (AOCS, 1998)}

Sampel minyak ditimbang sebanyak $10 \mathrm{~g}$ dalam erlenmeyer $100 \mathrm{~mL}$. Sampel kemudian ditambah dengan $50 \mathrm{~mL}$ etanol 95\% netral (Mallinckrodt Chemical, USA) dan dipanaskan dalam penangas air hingga minyak terlihat larut. Empat tetes indikator phenolftalein (Merck, Germany) 1\% ditambahkan sebelum melakukan titrasi. Titrasi dilakukan dengan $\mathrm{NaOH}$ (Merck, Germany) 0,01 N yang telah distandarisasi. Titik akhir titrasi ditunjukkan dengan terbentuknya warna merah muda stabil selama 30 detik.

\section{Analisis bilangan peroksida (AOCS, 1998)}

Sampel minyak ditimbang sebanyak $5 \mathrm{~g}$ dalam erlenmeyer $250 \mathrm{~mL}$. Pelarut $\mathrm{CH}_{3} \mathrm{COOH}-\mathrm{CHCl}_{3}$ (3:2) (Merck, Germany) sebanyak $30 \mathrm{~mL}$ ditambahkan dan campuran dikocok hingga semua minyak terlarut. Sebanyak 0,5 mL larutan KI (Merck, Germany) jenuh ditambahkan ke dalam erlenmeyer dan dikocok sesekali selama 2 menit. Campuran kemudian ditambah dengan $30 \mathrm{~mL}$ akuades dan dikocok $1 \mathrm{me}$ nit. Delapan tetes indikator pati $1 \%$ ditambahkan, kemudian dititrasi dengan $\mathrm{Na}_{2} \mathrm{~S}_{2} \mathrm{O}_{3}$ (Merck, Germany) 0,05 $\mathrm{N}$ hingga warna biru hilang. Blanko dibuat dengan cara yang sama tanpa penambahan sampel minyak.

\section{Rancangan percobaan dan prosedur analisis data}

Rancangan percobaan yang digunakan pada penelitian ini adalah rancangan acak lengkap (RAL) dengan 1 faktor. Faktor yang dilihat pengaruhnya pada percobaan ini yaitu jenis fortifikan terhadap retensi vitamin $A$ dan $\beta$-karoten minyak sawit yang difortifikasi. Dalam percobaan ini terdapat 4 taraf un- tuk jenis fortifikan yaitu vitamin A $45 \mathrm{IU} / \mathrm{g}$, MSM setara $45 \mathrm{lU} / \mathrm{g}$, kombinasi vitamin A $30 \mathrm{lU} / \mathrm{g}$ dan MSM setara $15 \mathrm{IU} / \mathrm{g}$ (campuran A), dan kombinasi vitamin A $15 \mathrm{lU} / \mathrm{g}$ dan MSM setara $30 \mathrm{lU} / \mathrm{g}$ (campuran B). Jenis bahan yang digoreng (shallow frying) adalah tahu, sedangkan bahan yang ditumis adalah tauge. Model yang digunakan adalah sebagai berikut:

$$
Y_{i j}=\mu+T_{i}+\varepsilon_{i j}
$$

dimana, $Y=$ retensi vitamin $A / \beta$-karoten pada jenis fortifikan ke-i ulangan ke-j, $\mu=$ rata-rata retensi vita$\min A / \beta$-karoten, $T_{j}=$ pengaruh jenis fortifikan ke-i, $\varepsilon_{\mathrm{ij}}=$ kekeliruan, berupa pengaruh acak pada jenis fortifikan ke-i dan ulangan ke-j, i= banyaknya jenis fortifikan, dan $j=$ banyaknya ulangan.

Retensi vitamin $A$ dan $\beta$-karoten pada minyak goreng fortifikasi setelah penggorengan ditentukan sebagai persen dari kandungan vitamin $A$ atau $\beta$ karoten dalam minyak goreng curah fortifikasi awal terhadap kandungan vitamin $A$ atau $\beta$-karoten dalam minyak goreng curah fortifikasi akhir (setelah penggorengan). Data retensi vitamin $A$ dan $\beta-k$ aroten yang diperoleh kemudian diolah menggunakan uji ragam (ANOVA). Apabila terdapat perbedaan yang nyata, maka dilanjutkan dengan uji lanjut Uji Tukey. Pengolahan data menggunakan program SPSS 21.

\section{HASIL DAN PEMBAHASAN}

\section{Karakteristik kimia minyak goreng dan MSM}

Karakteristik awal minyak goreng curah dan MSM yang digunakan untuk fortifikasi dengan target konsentrasi $45 \mathrm{IU} / \mathrm{g}$ MSM (dihitung dari kandungan $\beta$-karoten MSM) dan $45 \mathrm{IU} / g$ vitamin A disajikan pada Tabel 1. Minyak goreng curah memiliki kadar $\beta$ karoten yang sangat rendah, yaitu hanya sebesar

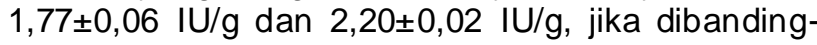
kan dengan MSM yang kadar $\beta-k$ arotennya mencapai $807,55 \pm 1,16$. Kandungan $\beta$-karoten yang tinggi pada MSM karena proses pemurnian Crude Palm Oil (CPO) menjadi MSM atau Neutralized Deodorized Red Palm Oil (NDRPO) dibuat tanpa melalui proses pemucatan (bleaching) (Ayustaningwarno, 2012).

Tabel 1. Karakteristik kimia minyak goreng curah dan minyak sawit merah (MSM)

\begin{tabular}{lcc}
\hline \multicolumn{1}{c}{ Analisis } & $\begin{array}{c}\text { Minyak Goreng } \\
\text { Curah }\end{array}$ & MSM \\
\hline $\begin{array}{l}\text { Kadar } \beta \text {-karoten } \\
\text { (IU/g) }\end{array}$ & $1,77 \pm 0,06$ & $847,75 \pm 3,10$ \\
$\begin{array}{l}\text { Bilangan peroksida } \\
\text { (mEq/kg) }\end{array}$ & $0,00 \pm 0,00$ & $6,79 \pm 0,01$ \\
$\begin{array}{l}\text { Asam lemak bebas } \\
\text { (\% asam palmitat) }\end{array}$ & $0,098 \pm 0,004$ & $0,130 \pm 0,005$ \\
\hline
\end{tabular}


Bilangan peroksida dari MSM lebih tinggi, yaitu 0,097 $\pm 0,00$ jika dibandingkan dengan minyak goreng curah $(0,00 \pm 0,00)$. Namun besaran ini masih memenuhi ketentuan SNI untuk standar minyak goreng sawit, yaitu kurang dari $10 \mathrm{mEq} / \mathrm{kg}$ (BSN, 2012). Sementara itu kadar asam lemak bebas MSM dan minyak goreng curah tidak terlalu berbeda yaitu $0,130 \pm 0,005 \%$ untuk MSM dan 0,098 $\pm 0,004 \%$ (dinyatakan sebagai \% asam palmitat) untuk minyak goreng curah. Nilai kadar asam lemak bebas ini juga masih memenuhi standar SNI minyak goreng sawit, yaitu maksimal 0,3\% asam palmitat (BSN, 2012).

Proses fortifikasi yang dilakukan merubah seluruh karakter dari minyak. Karakter minyak yang telah difortifikasi dapat dilihat pada Tabel 2. Hasil minyak fortifikasi ini telah memenuhi persyaratan SNI 7970:2012.

\section{Profil siklus penggorengan}

Penggorengan dilakukan dengan dua jenis siklus, yaitu siklus penggorengan pada hari yang berbeda dan siklus penggorengan pada hari yang sama. Satu siklus penggorengan didefinisikan sebagai satu kali penggorengan yang dimulai dari dipanaskannya minyak hingga mencapai suhu $170^{\circ} \mathrm{C}$, penggorengan tahu selama 2,5 menit, hingga waktu tunggu 15 menit setelah tahu diangkat. Sampling minyak pada titik ini di sebut h-1. Siklus penggorengan kedua dilakukan pada hari berikutnya dan dan disebut sebagai h-2. Siklus penggorengan ketiga dilakukan pada hari berikutnya dan sampling minyak setelah siklus ini disebut h-3. Pengukuran suhu penggorengan hanya dilakukan pada $\mathrm{h}-1$ untuk perlakuan penggorengan pada 3 hari yang berbeda (Gambar 2).

Gambar 2 menunjukkan bahwa walaupun penggorengan dilakukan pada suhu $\pm 170^{\circ} \mathrm{C}$, suhu bagian dalam tahu selama penggorengan hanya berkisar di suhu $100^{\circ} \mathrm{C}$. Gökmen et al. (2006) mengamati fenomena serupa pada kentang yang digoreng dengan metode deep-fat frying. Meskipun irisan kentang digoreng pada suhu $150^{\circ} \mathrm{C}$ selama 9 menit, suhu pada bagian dalam kentang hanya berkisar pada $103-105^{\circ} \mathrm{C}$. Terbatas nya kenaikan suhu ini merupakan akibat dari kandungan air pada bahan yang digoreng. Panas yang diterima dari minyak akan ditranfer ke dalam bahan dan digunakan untuk memanaskan bahan hingga mencapai suhu sedikit diatas titik didih air $\left(103-104^{\circ} \mathrm{C}\right)$. Setelah bahan mencapai suhu tersebut, sebagian besar kalor yang diterima digunakan untuk mengubah air menjadi uap. Digunakannya kalor dalam proses penguapan membuat suhu bagian dalam kentang tertahan di $103-105^{\circ} \mathrm{C}$. Suhu permukaan kentang juga hanya mencapai $120^{\circ} \mathrm{C}$.

Sementara itu satu siklus penggorengan pada hari yang sama didefinisikan sebagai satu kali penggorengan, yang dimulai dari pemanasan minyak hingga suhu $170^{\circ} \mathrm{C}$, penggorengan tahu putih selama 2,5 menit dan waktu tunggu 15 menit setelah tahu diangkat. Sampling minyak pada titik ini disebut juga sebagai penggorengan ke-1. Siklus penggorengan kedua dimulai setelah suhu minyak turun hingga mencapai $50^{\circ} \mathrm{C}$. Sampling minyak pada titik ini disebut penggorengan ke-2. Hal yang sama dilakukan pula pada siklus penggorengan ke-3. Profil suhu penggorengan pada ketiga siklus ini disajikan pada Gambar 3. Semakin banyak jumlah penggorengan yang dilakukan, maka minyak makin cepat menjadi panas. Hal ini disebabkan oleh jumlah minyak yang semakin berkurang karena digunakan dalam sampling minyak.

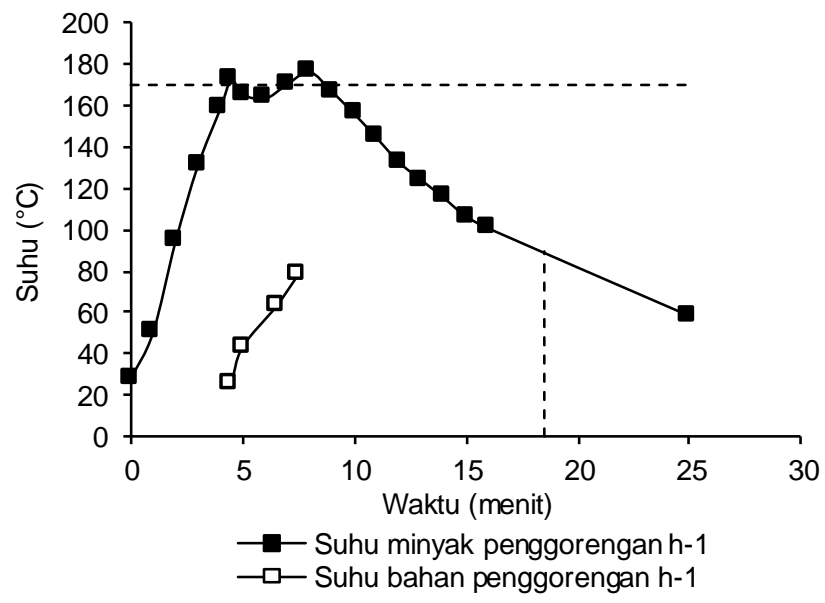

Gambar 2. Suhu minyak pada penggorengan tahu hari pertama $(\mathrm{h}-1)$

\section{Retensi vitamin A dan $\beta$-karoten pada minyak goreng curah}

Besaran vitamin $A$ dan $\beta$-karoten yang masih dikandung oleh minyak goreng curah setelah proses penggorengan disajikan pada Tabel 3. Minyak fortifikasi yang digunakan menggoreng berulang pada hari yang berbeda memiliki retensi fortifikasi yang tidak berbeda nyata pada taraf uji $5 \%$.

Tabel 2. Karakteristik kimia minyak goreng curah yang difortifikasi dengan vitamin A dan MSM

\begin{tabular}{lccc}
\multicolumn{1}{c}{ Minyak Difortifikasi } & $\begin{array}{c}\text { Rata-Rata Fortifikasi } \\
\text { (IU/g) }\end{array}$ & $\begin{array}{c}\text { Bilangan Peroksida } \\
\text { (mEq/kg) }\end{array}$ & $\begin{array}{c}\text { Asam Lemak Bebas (\% } \\
\text { Asam Palmitat) }\end{array}$ \\
\hline 45 IU/g MSM & $47,08 \pm 0,86$ & $0,00 \pm 0,00$ & $0,102 \pm 0,000$ \\
45 IU/g vitamin A & $59,69 \pm 3,13$ & $0,00 \pm 0,00$ & $0,138 \pm 0,001$ \\
Campuran A (30 IU/g vitamin A dan & $45,64 \pm 1,66$ & $0,00 \pm 0,00$ & $0,082 \pm 0,003$ \\
15 IU/g MSM) & $45,95 \pm 1,51$ & $0,00 \pm 0,00$ & $0,080 \pm 0,000$ \\
Campuran B (15 IU/g vitamin A dan & 400 IU/g MSM) & & \\
\hline
\end{tabular}




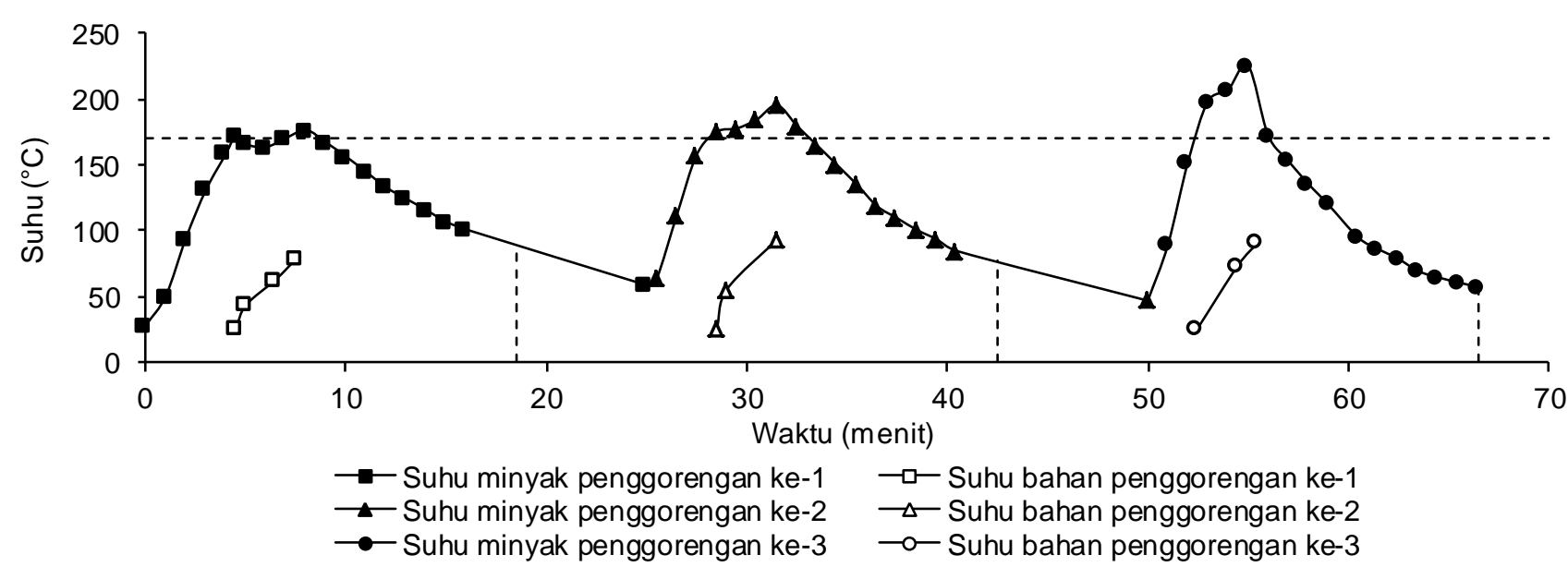

Gambar 3. Profil suhu minyak goreng dan tahu pada penggorengan berulang hari yang sama

Tabel 3. Retensi $\beta$-karoten dan vitamin A pada minyak goreng curah yang difortifikasi selama proses penggorengan tahu berulang

\begin{tabular}{|c|c|c|c|c|c|c|}
\hline \multirow{3}{*}{ Minyak Difortifikasi } & \multicolumn{3}{|c|}{$\begin{array}{l}\text { Penggorengan Berulang Hari yang } \\
\text { Berbeda }\end{array}$} & \multicolumn{3}{|c|}{$\begin{array}{c}\text { Penggorengan Berulang Hari yang } \\
\text { Sama }\end{array}$} \\
\hline & \multicolumn{3}{|c|}{ Retensi Penggorengan h- (\%) } & \multicolumn{3}{|c|}{ Retensi Penggorengan ke- (\%) } \\
\hline & 1 & 2 & 3 & 1 & 2 & 3 \\
\hline $45 \mathrm{IU} / \mathrm{g} \mathrm{MSM}$ & $85,52^{a}$ & $58,25^{a}$ & $25,41^{a}$ & $80,40^{a}$ & $53,70^{a}$ & $23,58^{a}$ \\
\hline $45 \mathrm{lU} / \mathrm{g}$ Vitamin A & $88,22^{a}$ & $74,91^{\mathrm{D}}$ & $63,99^{\mathrm{D}}$ & $86,48^{a}$ & $69,04^{D}$ & $64,13^{\mathrm{D}}$ \\
\hline $\begin{array}{l}\text { Campuran A } \\
\text { (30 IU/g vitamin A dan } 15 \mathrm{lU} / \mathrm{g} \mathrm{MSM} \text { ) }\end{array}$ & $86,69^{a}$ & $72,13 b^{c}$ & $51,17^{\mathrm{C}}$ & $84,61^{\mathrm{a}}$ & $73,75^{\mathrm{D}}$ & $49,75^{\mathrm{C}}$ \\
\hline $\begin{array}{l}\text { Campuran B } \\
\text { (15 IU/g vitamin A dan } 30 \mathrm{lU} / \mathrm{g} \mathrm{MSM})\end{array}$ & $86,23^{\mathrm{a}}$ & $69,54^{\mathrm{c}}$ & $48,88^{\mathrm{C}}$ & $89,43^{a}$ & $69,17^{\circ}$ & $44,74^{\mathrm{a}}$ \\
\hline
\end{tabular}

Keterangan: ${ }^{a}$ Angka-angka pada kolom yang sama yang diikuti oleh huruf yang sama tidak berbeda nyata pada taraf uji $5 \%$ (uji lanjut Tukey)

Pada penggorengan di h-2 dan h-3, minyak yang difortifikasi dengan MSM memiliki retensi paling rendah $(58,25$ dan $25,41 \%)$ dibandingkan dengan ketiga minyak fortifikasi lainnya yang semuanya mengandung vitamin $A$. Secara umum pada $h-2$ dan h-3 minyak yang difortifikasi dengan retinil palmitat memiliki retensi vitamin A paling tinggi $(74,91$ dan 63,99\%). Pada penggorengan h-3 minyak ini bahkan memiliki retensi sebesar dua kali retensi minyak yang difortifikasi dengan MSM, yang hanya mencapai sebesar $23,58 \%$ jumlah $\beta$-karoten awal. Minyak dengan fortifikan campuran A dan B memiliki nilai retensi diantara keduanya, yaitu 74,91 dan 72 , $13 \%$ pada penggorengan $\mathrm{h}-2$ dan 63,99 dan $51,18 \%$ pada $\mathrm{h}-3$.

Pada penggorengan berulang pada hari yang sama, keempat jenis minyak memiliki retensi fortifikan yang berada di kisaran yang sama pada penggorengan pertama $(80,40-89,43 \%)$. Penggorengan kedua menyebabkan minyak goreng yang difortifikasi oleh MSM memiliki nilai retensi paling rendah $(53,70 \%)$. Sementara itu, minyak yang difortifikasi dengan retinil palmitat dan fortifikan campuran $A$ dan $B$ memiliki nilai retensi yang tidak berbeda nyata pada taraf uji $5 \%(69,04$ dan $73,75 \%)$. Pada penggorengan ketiga, grafik nilai retensi minyak goreng yang difortifikasi dengan MSM menunjukkan penurunan yang paling ekstrim. Penurunan ini dilihat dari nilai retensi minyak dengan fortifikasi MSM pada penggorengan ke-3 yang hanya mencapai sebesar $23,58 \%$. Fenomena ini menegaskan bahwa minyak goreng dengan fortifikasi MSM masih merupakan minyak yang memiliki nilai retensi paling rendah. $\mathrm{Pa}$ da penggorengan ketiga ini minyak goreng dengan fortifikan retinil palmitat memiliki nilai retensi yang paling tinggi $(64,13 \%)$. Sementara itu minyak goreng dengan fortifikan campuran $A$ dan $B$ memiliki nilai retensi di antara minyak goreng fortifikasi retinil palmitat dan minyak goreng dengan fortifikan MSM. Nilai retensi campuran $\mathrm{A}(64,13 \%)$ lebih tinggi dibandingkan campuran B $(49,76 \%)$.

Suhu minyak yang semakin tinggi seiring dengan jumlah ulangan pada proses penggorengan (Gambar 3) diduga memengaruhi penurunan jumlah $\beta$-karoten. Secara umum penurunan jumlah $\beta$-karoten pada penggorengan kedua lebih drastis dibandingkan pada penggorengan pertama, dan penurunan $\beta$-karoten pada penggorengan ketiga lebih drastis dibanding pada penggorengan kedua. Achir et al. (2010) mengamati bahwa laju degradasi $\beta$-karoten akan meningkat seiring dengan tingginya suhu yang digunakan. Souganidis et al. (2013) juga mencan- 
tumkan bahwa proses berulang akan mengurangi sifat antioksidan dari $\beta$-karoten dengan drastis. Selain itu trans- $\beta$-karoten yang terdapat dalam minyak akan terdegradasi menjadi 13-cis dan 9-cis- $\beta$-karoten selama penggorengan. Degradasi $\beta$-karoten akan menyebabkan minyak berubah menjadi berwarna keabuan dan menghitam. Terdapatnya efek yang tidak diinginkan ini menyebabkan penelitian mengenai $\beta$-karoten dari MSM sebagai sumber vitamin A lebih banyak berfokus kepada penggunaannya yang tidak terkait dengan proses penggorengan.

Lebih lanjut, Souganidis et al. (2013) telah membandingkan stabilitas retinil palmitat dan MSM. Dijelaskan bahwa meskipun vitamin A bersifat sangat tidak stabil, retinil palmitat merupakan ester yang lebih stabil dibandingkan dengan bentuk sebelumnya. Retinil palmitat sendiri merupakan vitamin $A$ yang telah mengalami esterifikasi dengan asam palmitat. Puysuwan et al. (2007) mengamati retensi vitamin A dalam bentuk ester palmitat yang digunakan sebagai fortifikan dalam minyak goreng. Minyak sawit yang digunakan untuk menggoreng pada suhu $120^{\circ} \mathrm{C}$ selama 5 menit memiliki retensi vitamin $A$ sekitar 96,94 hingga 97,58\%, tergantung dari bahan penggorengan yang digunakan. Jika proses dilanjutkan hingga 10 menit, retensi vitamin $A$ berkurang menjadi sekitar 95,39 hingga 96,56\%. Pada suhu $170^{\circ} \mathrm{C}$, proses menggoreng selama 5 menit menghasilkan minyak sawit yang memiliki nilai retensi vitamin A sebesar 88,89 hingga 90,71\%. Jika proses dilanjutkan hingga waktu 10 menit, retensi vitamin $A$ berkurang menjadi 86,49 hingga $87,39 \%$.

\section{Perubahan bilangan peroksida}

Penggorengan berulang di hari yang sama maupun penggorengan berulang di hari yang berbeda menyebabkan bilangan peroksida minyak membentuk pola yang serupa. Gambar 4 dan 5 mengilustrasikan pola pergerakan besaran bilangan peroksida pada minyak. Secara umum, bilangan peroksida pada minyak akan mengalami peningkatan hingga penggorengan $\mathrm{h}-2$, namun turun kembali pada penggorengan h-3. Hasil ini sejalan dengan penelitian yang dilakukan oleh Abdulkarim et al. (2007). Penelitian ini menggunakan beberapa jenis minyak yang digunakan selama 5 hari penggorengan pada suhu $185 \pm 5^{\circ} \mathrm{C}$. Bilangan peroksida pada minyak tersebut mengalami peningkatan hingga hari ke empat penggorengan. Pada hari ke lima, bilangan peroksida pada minyak yang digunakan justru mengalami penurunan. Fenomena ini dijelaskan lebih lanjut oleh Abdulkarim et al. (2007), peroksida bersifat tidak stabil terhadap suhu penggorengan. Seiring dengan berjalannya proses kerusakan minyak, hidroperoksida, yang merupakan produk awal dari oksidasi lemak, akan terdekomposisi. Menurut Kim et al. (2007) dekomposisi hidroperoksida menghasilkan dimer, trimer, dan polimer teroksidasi, serta komponen volatil seperti aldehid, keton, alkohol, hidrokarbon, dan furan, yang menyebabkan ketengikan pada minyak.

Secara umum, minyak yang difortifikasi dengan MSM memiliki bilangan peroksida yang paling rendah (Gambar 4 dan 5). Hal ini diduga disebabkan karena MSM mengandung antioksidan yang dapat menghambat oksidasi selama penggorengan. Van Rooyen et al. (2008) mencantumkan bahwa MSM mengandung $800 \mathrm{ppm}$ vitamin E (70\% tokotrienol dan $30 \%$ tokoferol) yang dapat bersinergi dengan karotenoid sebagai antioksidan. MSM juga mengandung komponen minor yang memiliki aktivitas antioksidan seperti ubiquinon (dalam bentuk koenzim $\mathrm{Q}_{10}$ ) dan fitosterol.

\section{Perubahan asam lemak bebas}

Perubahan kadar asam lemak bebas pada minyak selama proses penggorengan disajikan pada Tabel 4. Pada perlakuan penggorengan berulang di hari yang sama maupun di hari yang berbeda, kadar asam lemak bebas pada minyak yang difortifikasi dengan vitamin A tidak menunjukkan perbedaan yang signifikan pada setiap pengulangan penggorengan.

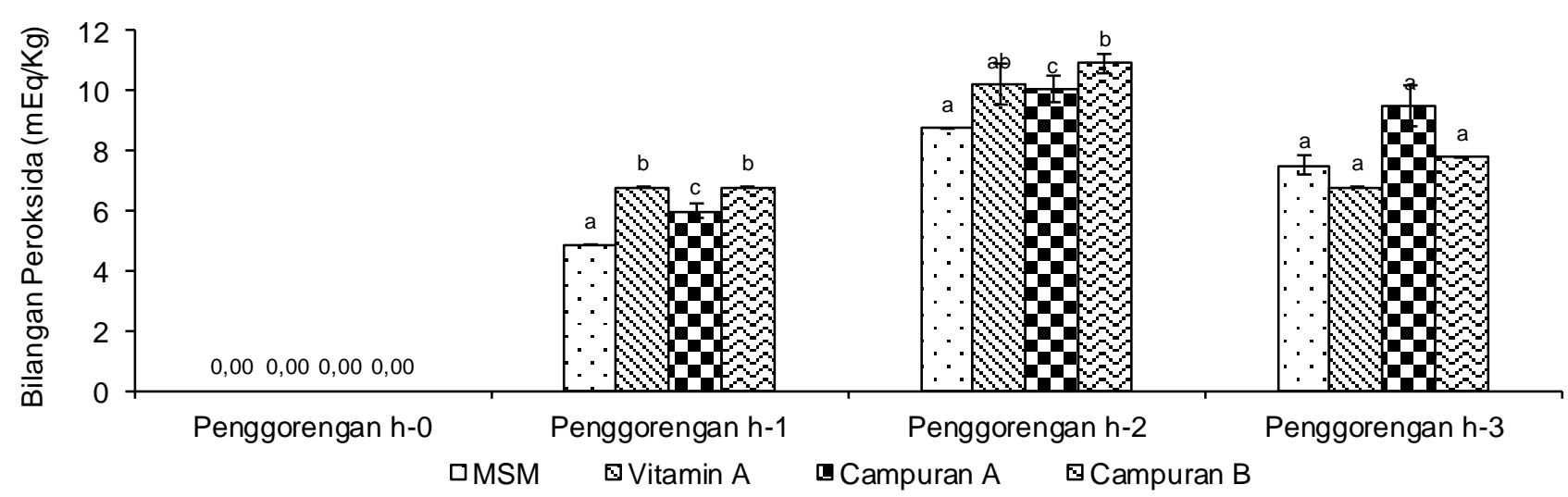

Gambar 4. Bilangan peroksida minyak goreng curah yang difortifikasi untuk penggorengan tahu pada 3 hari yang berbeda 


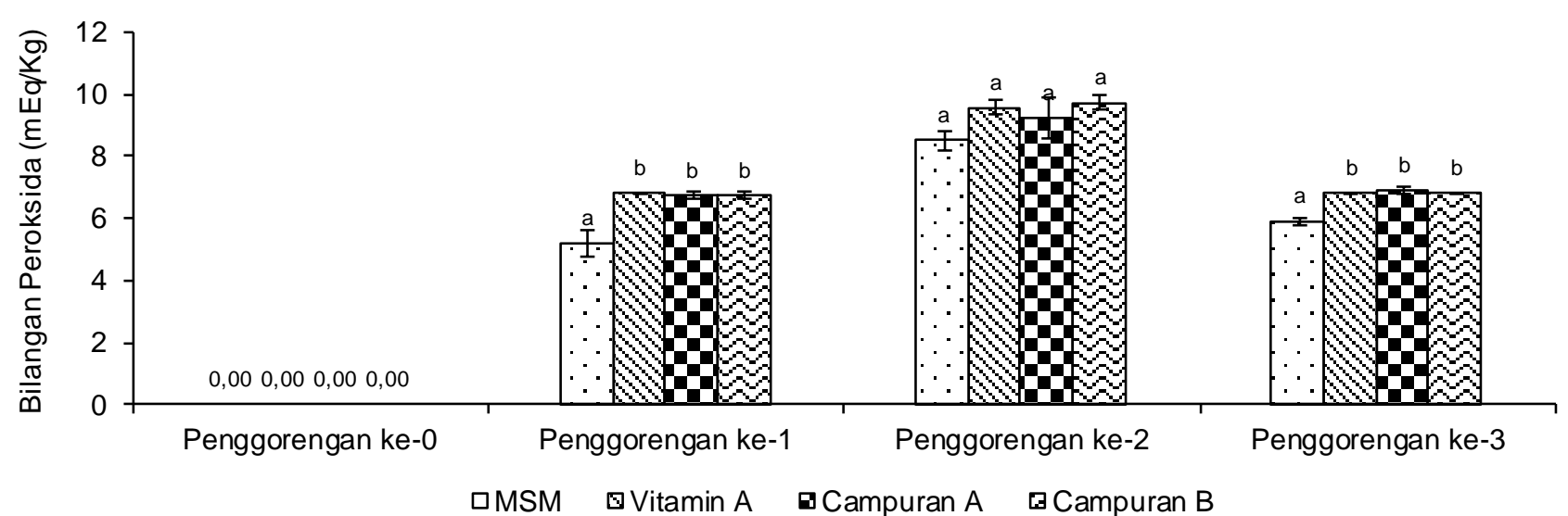

Gambar 5. Bilangan peroksida minyak goreng curah yang difortifikasi pada 3 kali penggorengan tahu pada hari yang sama

Tabel 4. Perubahan kadar asam lemak bebas minyak goreng curah yang difortifikasi selama penggorengan tahu berulang

\begin{tabular}{|c|c|c|c|c|c|c|c|}
\hline \multirow[t]{2}{*}{ Minyak Difortifikasi } & \multicolumn{4}{|c|}{$\begin{array}{c}\text { Penggorengan Berulang Hari yang Berbeda } \\
\text { Bilangan Asam (\% Asam Palmitat) } \\
\text { Penggorengan h- } \\
\end{array}$} & \multicolumn{3}{|c|}{$\begin{array}{c}\text { Penggorengan Berulang Hari yang Sama } \\
\text { Bilangan Asam (\% Asam Palmitat) } \\
\text { Penggorengan ke- }\end{array}$} \\
\hline & 0 & 1 & 2 & 3 & 1 & 2 & 3 \\
\hline $45 \mathrm{lU} / \mathrm{g} \mathrm{MSM}$ & $0,102^{a}$ & $0,111^{\circ}$ & $0,113^{0}$ & $0,115^{\circ}$ & $0,107^{\mathrm{aO}}$ & $0,111^{\circ}$ & $0,120^{C}$ \\
\hline $\begin{array}{l}45 \mathrm{IU} / \mathrm{g} \text { Vitamin } \mathrm{A} \\
\text { Campuran } \mathrm{A}\end{array}$ & $0,138^{\mathrm{a}}$ & $0,136^{\mathrm{a}}$ & $0,140^{\mathrm{a}}$ & $0,137^{\mathrm{a}}$ & $0,136^{\mathrm{a}}$ & $0,137^{\mathrm{a}}$ & $0,139^{a}$ \\
\hline $\begin{array}{l}\text { (30 IU } / \mathrm{g} \text { vitamin A dan } \\
15 \mathrm{IU} / \mathrm{g} \mathrm{MSM})\end{array}$ & $0,082^{a}$ & $0,096^{b}$ & $0,101^{\mathrm{b}}$ & $0,113^{c}$ & $0,097^{b}$ & $0,103^{b c}$ & $0,107^{c}$ \\
\hline $\begin{array}{l}\text { Campuran B } \\
\text { (15 IU/g vitamin A dan } \\
30 \mathrm{lU} / \mathrm{g} \text { MSM) }\end{array}$ & $0,080^{a}$ & $0,092^{b}$ & $0,101^{\mathrm{c}}$ & $0,113^{d}$ & $0,096^{b}$ & $0,098^{b c}$ & $0,106^{c}$ \\
\hline
\end{tabular}

Keterangan: ${ }^{a}$ Angka-angka pada baris yang sama yang diikuti oleh huruf yang sama tidak berbeda nyata pada taraf uji $5 \%$ (uji lanjut Tukey)

Minyak dengan fortifikasi MSM, campuran A, dan campuran $B$ mengalami peningkatan kadar asam lemak bebas seiring dengan jumlah penggorengan yang dilakukan. Hal ini sesuai dengan (Ali dan Abdurrhman, 2013) yang menyatakan bahwa kandungan asam lemak bebas pada minyak yang digunakan untuk menggoreng pada umumnya akan bertambah seiring dengan jumlah perlakuan penggorengan. Di sisi lain, lamanya penggorengan tidak memengaruhi proses hidrolisis minyak. Studi ini juga menyatakan bahwa proses hidrolisis lebih mudah terjadi pada minyak yang memiliki asam lemak bebas rantai pendek dan tak jenuh, sementara asam lemak yang dominan pada minyak sawit adalah miristat, palmitat, stearat, oleat dan linoleat. Komposisi asam lemak ini menjelaskan mengapa peningkatan kandungan asam lemak bebas pada minyak setelah proses penggorengan tidak mengalami peningkatan yang ekstrim.

\section{Yield fortifikan pada perlakuan tumis}

Yield fortifikan merupakan rasio jumlah fortifikan yang terdapat pada tumis tauge dibandingkan dengan jumlah fortifikan awal yang dikandung pada minyak yang digunakan untuk menumis. Yield fortifikan pada hasil tumisan diilustrasikan pada Gambar 6. Pada Gambar 6 dapat dilihat bahwa penumisan menggunakan minyak yang difortifikasi dengan vitamin A palmitat menghasilkan yield yang lebih tinggi $(64,37 \%)$ dibandingkan dengan penumisan dengan menggunakan minyak yang difortifikasi dengan MSM (34,68\%). Penumisan dengan minyak yang difortifikasi oleh fortifikan campuran A dan B menghasilkan yield masing-masing 50,60 dan 53,42\%.

Data kandungan vitamin $A$ dan $\beta$-karoten pada hasil tumisan selanjutnya digunakan untuk menghitung kontribusi fortifikan untuk pemenuhan kecukupan gizi tersebut jika hasil tumisan dikonsumsi. Hasil perhitungannya disajikan pada Tabel 5. Fortifikan $\beta$ karoten pada MSM memberikan kontribusi pemenuhan kecukupan vitamin A paling rendah dan fortifikan vitamin A memberikan kontribusi paling tinggi. Data ini sesuai dengan karakteristik retensi fortifikan pada minyak goreng curah terfortifikasi yang digunakan pada penggorengan berulang (Tabel 3). 
Tabel 5. Kontribusi kandungan fortifikan pada $150 \mathrm{~g}$ tumis tauge terhadap AKG vitamin A

\begin{tabular}{lccccc}
\hline \multirow{2}{*}{ Kelompok Usia } & \multirow{2}{*}{ AKG vitamin A $(\mu \mathrm{g} \text { retinol })^{1)}$} & \multicolumn{4}{c}{ Kontribusi fortifikan terhadap AKG vitamin A (\%) } \\
\cline { 3 - 6 } & & MSM & Vitamin A & Campuran A & Campuran B \\
\hline Laki-laki dewasa & 600 & 32,71 & 77,44 & 51,10 & 48,03 \\
Wanita dewasa & 500 & 39,26 & 92,93 & 61,32 & 57,64 \\
\hline
\end{tabular}

Sumber:" Meiliana et al., 2014

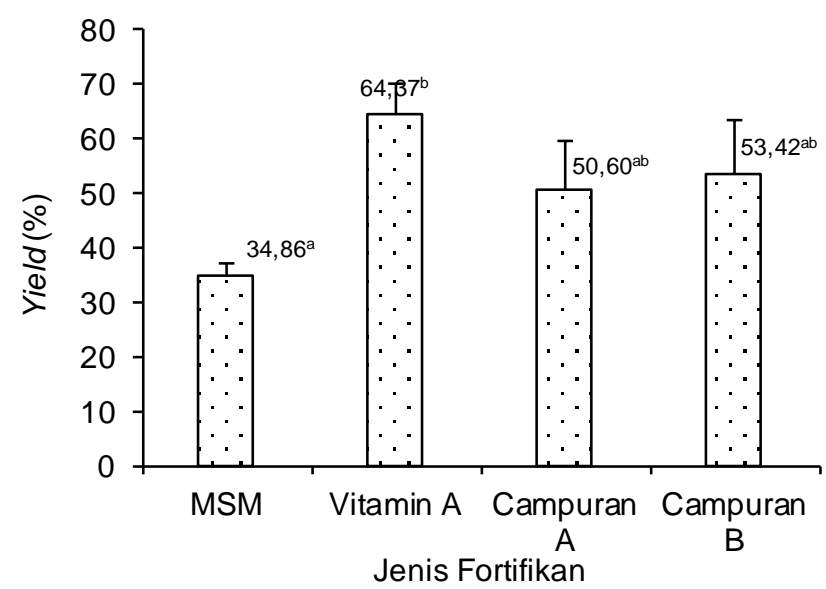

Gambar 6. Retensi vitamin A dan $\beta$-karoten sampel tumis tauge dengan 4 minyak goreng curah yang mengandung fortifikan berbeda $(\alpha=0,1)$

\section{KESIMPULAN}

Jenis fortifikan yang ditambahkan pada minyak sawit curah memengaruhi stabilitas vitamin $A$ maupun $\beta$-karoten dari minyak terfortifikasi tersebut. Retensi fortifikan pada penggorengan berulang pada hari yang sama dengan penggorengan berulang pada hari yang berbeda mempunyai pola yang sama untuk setiap jenis fortifikan yang digunakan. Minyak yang difortifikasi dengan vitamin A (retinil palmitat) memiliki retensi paling tinggi. Minyak yang difortifikasi dengan MSM memiliki retensi paling rendah, sementara minyak yang difortifikasi dengan fortifikan campuran A dan B memiliki retensi diantara keduanya. Bilangan peroksida dari minyak goreng curah terfortifikasi secara umum mengalami peningkatan hingga penggorengan kedua, dan mengalami penurunan pada penggorengan ketiga. Perubahan kadar asam lemak bebas pada keempat jenis minyak goreng curah terfortifikasi yang digunakan relatif kecil.

Yield fortifikan pada tumis tauge dipengaruhi oleh jenis fortifikan yang ditambahkan pada minyak. Minyak yang difortifikasi vitamin A memiliki yield fortifikan paling tinggi $(64,37 \%)$, diikuti oleh minyak yang difortifikasi oleh fortifikan campuran B (53, $42 \%)$, campuran A $(50,60 \%)$, dan MSM $(34,86 \%)$. Hasil tumisan yang mengandung fortifikan menyumbang pemenuhan kecukupan vitamin A sebesar $32,71-92,93 \%$.

\section{UCAPAN TERIMAKASIH}

Peneliti mengucapkan terima kasih kepada Yayasan Kegizian untuk Pengembangan Fortifikasi Pangan Indonesia (KFI) yang telah memberikan dana penelitian.

\section{DAFTAR PUSTAKA}

[AOAC] Association of Official Analytical Chemist. 1984. Official Method of Analysis of The Association of Official Analytical Chemist $14^{\text {th }}$ edition. Association of Official Analytical Chemist Inc, Arlington, USA.

[AOCS] American Oil Chemist Society. 1998. Official Methods and Recommended Practice of the American Oil Chemists' Society 5th Edition. Champaign III, AOCS Press, USA.

[BSN] Badan Standarisasi Nasional. 2012. Minyak goreng sawit. http://sisni.bsn.go.id/index.php/sni _main/sni/detail_sni/14332 [14 Maret 2013].

Abdulkarim SM, Long K, Lai OM, Muhammad SKS, Ghazali HM. 2007. Frying quality and stability of high-oleic Moringa oleifera seed oil in compareson with other vegetable oils. Food Chem 105: 1382-1389. DOI: 10.1016/j.foodchem.2007.05.0 13.

Ali ASM, Abdurrhman AM. 2013. Determination of free fatty acids in palm oil samples by nonaqueous flow injection using salicyaldehide-2,4dinitrophenylhydrazone as colorimetric reagent. Chem Mater Eng 1: 96-103.

Achadi E, Arifah A, Muslimatun S, Anggondowati T, Setiarini A. 2010. Efektivitas program fortifikasi minyak goreng dengan vitamin A terhadap status gizi anak sekolah di Kota Makassar. J Kes Mas Nasional 4: 255-261. DOI: 10.21109/kes mas.v4i6.164.

Achir N, Randrianatoandro VA, Bohoun P, Laffargue A, Avallone S. 2010. Kinetics study of $\beta$-carotene and lutein degradation in oils during heat treatment. Eur J Lipid Sci Technol 112: 349-361. DOI: $10.1002 /$ ejlt.200900165.

Akhtar H, Tahir L, Mahmud S, Hamid S. 2012. Loss of vitamin $A$ in fortified edible oils and ghee during cooking in asian traditional style. Bangladesh J Sci Ind Res 47: 243-248. DOI: 10.3329/ bjsir.v47i2.11461. 
Andarwulan N, Gitapratiwi D, Laillou A, Fitriani D, Hariyadi P, Moench-Pfanner R, Martianto D. 2014. Quality of vegetable oil prior to fortifica tion is an important criteria to achieve a health impact. Nutrients 6: 5051-5060. DOI: 10.3390/ nu6115051.

Ayustaningwarno F. 2012. Proses pengolahan dan aplikasi minyak sawit merah pada industri pangan. Vitasphere 2: 1-11.

Bohn T. 2008. Bioavailability of non-provitamin A carotenoids. Curr Nutr Food Sci 4: 240-258. DOI: $10.2174 / 157340108786263685$.

Chiu MC, Coutinho C, Gonçalves LAG. 2009. Carotenoids concentration of palm oil using mem brane technology. Desalination 245: 783-786. DOI: 10.1016/j.desal.2009.03.002.

Dever JT, Surles R, Davis CR, Tanumihardjo SA. 2011. [alpha]-retinol is distributes through serum retinol-binding protein-independent mechanisms in the lactating sow-nursing piglet Dyad13. J Nutr 141: 42-47. DOI: 10.3945/jn.110.1275 97.

Fiedler JL, Afidra R. 2010. Vitamin A fortification in Uganda: comparing the feasibility, coverage, costs, and cost-effectiveness of fortifying vegetable oil and sugar. Food Nutr Bull 31: 193-205. DOI: $10.1177 / 156482651003100202$.

Folch J, Lees M, Stanley HS. 1956. A simple method for the is olation and purification of total lipides from animal tissues. J Biol Chem 226: 497-509.

Gökmen V, Palazglu TK, Senyuva HZ. 2006. Relation between the acrylamide formation and time-temperature history of surface and core regions of french fries. J Food Eng 77: 972-976. DOI: 10.1016/j.jfoodeng-2005.03.030.
Kim HJ, Hahm TS, Min DB. 2007. Hydroperoxide as a prooxidant in the oxidative stability of soybean oil. J Am Oil Chem Soc 84: 349-355. DOI: 10. 1007/s11746-007-1044-6.

Marliyati SA, Hardinsyah, Rucita N. 2010. Pemanfaatan RPO (red palm oil) sebagai sumber provitamin $A$ alami pada produk mi instan untuk anak balita. J Gizi Pangan 5: 31-38. DOI: 10.25 182/jgp.2010.5.1.31-38.

Meiliana, Roekistiningsih, Sutjiati E. 2014. Pengaruh proses pengolahan daun singkong (Manihot es culeta crantz) dengan berbagai perlakuan terhadap kadar $\beta$-karoten. Indonesian J Hum Nutr 1: 23-34.

Nadimin, Tamrin A. 2013. Pengaruh fortifikasi vitamin A pada minyak goreng curah terhadap ting kat kesukaan konsumen pada makanan gorengan. Media Gizi Pangan 17: 62-69.

Oni OA. 2012. Consumer willingness to pay for vitamin $A$ fortification in vegetable oil in south western Nigeria: a contingent valuation approach. Nigerian J Agric Food Envir 8: 66-73.

Puysuwan L, Chavasit V, Sungpuag P, Hedgar D, Punchivai T. 2007. Feasibility and use of vitamin A-fortified vegetable oils among consumers of different socioeconomic status in Thai land. Food Nutr Bull 28: 181-188. DOI: 10.1177/ 156482650702800207.

Souganidis E, Laillou A, Leyvraz M, MoenchPfanner R. 2013. A comparison of retinyl palmitate and red palm oil $\beta$-carotene as strategies to address vitamin A deficiency. Nutrients 5: 3257-32711. DOI: 10.3390/nu5083257.

Van Rooyen J, Esterhuye AJ, Engelbrecht AM, Du Toit EF. 2008. Health benefit of a natural carotenoid rich oil: a proposed mechanism of protecttion against ischaemia/reperfusion injury. Asia Pac J Clin Nutr 17: 316-319. 